\title{
INCREASING WATER PRODUCTIVITY OF LOWLAND RICE THROUGH THE WATER SAVING TECHNIQUES AND CROP MANAGEMENT IN RESPONSE TO DROUGHT
}

(Peningkatan Produktivitas Air Sawah melalui Teknik Penghematan Air dan Pengelolaan

Tanaman dalam Merespon Kekeringan)

Didiek Setiobudi dan Hasil Sembiring

Indonesian Center for Rice Research

JI. Raya 9 Sukamandi. Ciasem. Subang. West Java 41256

\begin{abstract}
The water saving technology for lowland rice cultivation was very crucial because of in the future irrigation water become scarce and competed with other sectors. The lowering of the availability of irrigation water had the impact for sustainability of rice production. The review of the paper described the pattern of basic water requirement, yield responses of several lowland rice varieties to moisture stress, days interval irrigation and the alternatives of water saving techniques for improving yield and water productivity. The pattern of the actual water requirement (ET+P\&S) showed the maximum value of $8.8 \mathrm{~mm} /$ day $(1.02 \mathrm{lt} / \mathrm{sec} / \mathrm{ha})$ for high yielding varieties (HYV) that occurred from heading to $50 \%$ flowering. Under limited water supply, irrigation water should be applied that period to prevent yield loss. Soil moisture stress at moderate level (- 0.5 bar) from heading to full flowering was significantly decreased yield about $30 \%$ when compared with the yield of continuously flooded $3 \mathrm{~cm}$ depth. This period was a critical period of HYV to soil moisture stress. For rotational irrigation purposes, information of the optimum days interval irrigation was important. It was found that 3 days irrigation interval was a critical limit for HYV to achieve higher yield. The SRI model of rice cultivation had the lowest rice yield in the lowland soil, poor drainage, clay soil texture and low permeability. The modified irrigation of the SRI plus fertilizer $N$ based on LCC readings gave a greater yield as well as water productivity. The hybrid and NPT line rice varieties had higher yield components and grain yield than Ciherang variety. Ciherang variety was not favor to grown for the wet season, it was more productive when grown in dry season even with AWD irrigation model. The plant spacing of $25 \mathrm{~cm} \times 25 \mathrm{~cm}$ gave higher number of panicle/hill and number of spikelet/panicle under both AWD and continuously flooded 3 $\mathrm{cm}$ depth for dry and wet season consistently. The fertilizer N management based on SSNM with low and high rates for the early vegetative stage were not significantly affected all yield components and grain yield. The AWD irrigation could save irrigation water about $18 \%$ when compared to the continuously flooded conditions. The grain yield of the hybrid, inbred and NPT line rice varieties was higher for the dry season than wet season under both AWD irrigation and continuous flooding consistently.
\end{abstract}

Keywords : crop management, critical period, lowland cultivation, rice, water saving

Penyerahan naskah

Diterima untuk diterbitkan
: 01 Oktober 2009

:02 November 2009 


\section{INTRODUCTION}

In Asia, the availability of freshwater for agriculture is declining, while demand for rice will increase because of population growth. Rice is a heavy consumer of freshwater and approximately $50 \%$ of the freshwater used in Asian agriculture is used for rice production. Facing the increasing demand for food combined with the increasing scarcity of water, rice production in Asia need to produce more rice with less water (Belder,et al., 2002).

In recent years, these extreme climatic events have become more frequents and their impact has been more severe. Between 1844 and 1960, drought happened on average every four years, but between 1961 and 2006, they occurred every three years,. The El-Nino event of 1997-1998 was the most severe for 50 years, indeed, 1998 was the hottest year in the twentieth century. In the future, parts of Indonesia, particularly in regions located south of the equator, could have longer dry seasons and shorter but more intense wet season with the kind of changes in the rainfall pattern (UNDP Indonesia, 2007).

Irrespective of the individual objectives of the particular irrigation system, there are three main objectives for the irrigated agricultural sector : (1) production, thereby ensuring that the investments made in irrigation infrastructure result in greater and more stable food supplies to the population or raw materials for subsequent processing, (2) equity, to ensure that the maximum number of people will share in the benefits provided by the provision of irrigation facilities and (3) sustainability, to ensure that investments made and benefits derived will be long lasting and represent a transformation from unreliable and efficient irrigated agriculture (Murray Rust, 1990).

The poor infrastructure, lack of water control and low water use efficiency at the tertiary level. Water flows directly from plot to plot, this often leads to conflict of interest in water management. The dominant practice in rice production is flooded irrigation, which requires large amounts of water. Flooded rice fields are important sources of methane emissions, which is one of the major greenhouse gases associated with global climate change.

In addition, nutrient use efficiencies in flooded rice are often low because of high losses, resulting in contamination and high fertilizer costs for farmers. Hence, water management practices are required to increase water use efficiency in rice production while maintaining productivity (Shi, et al., 2002). 


\section{The Existing of Irrigation Canal Networks and It's Relation to Water Saving}

The Indramayu regency was the one of service area of PJT II which located in the eastern part with the distance about $70 \mathrm{~km}$ from the Jatiluhur reservoir. Indramayu area have largest lowland rice area however it's often suffered by water shortage and sometimes a part of area has failed to harvest during dry season.

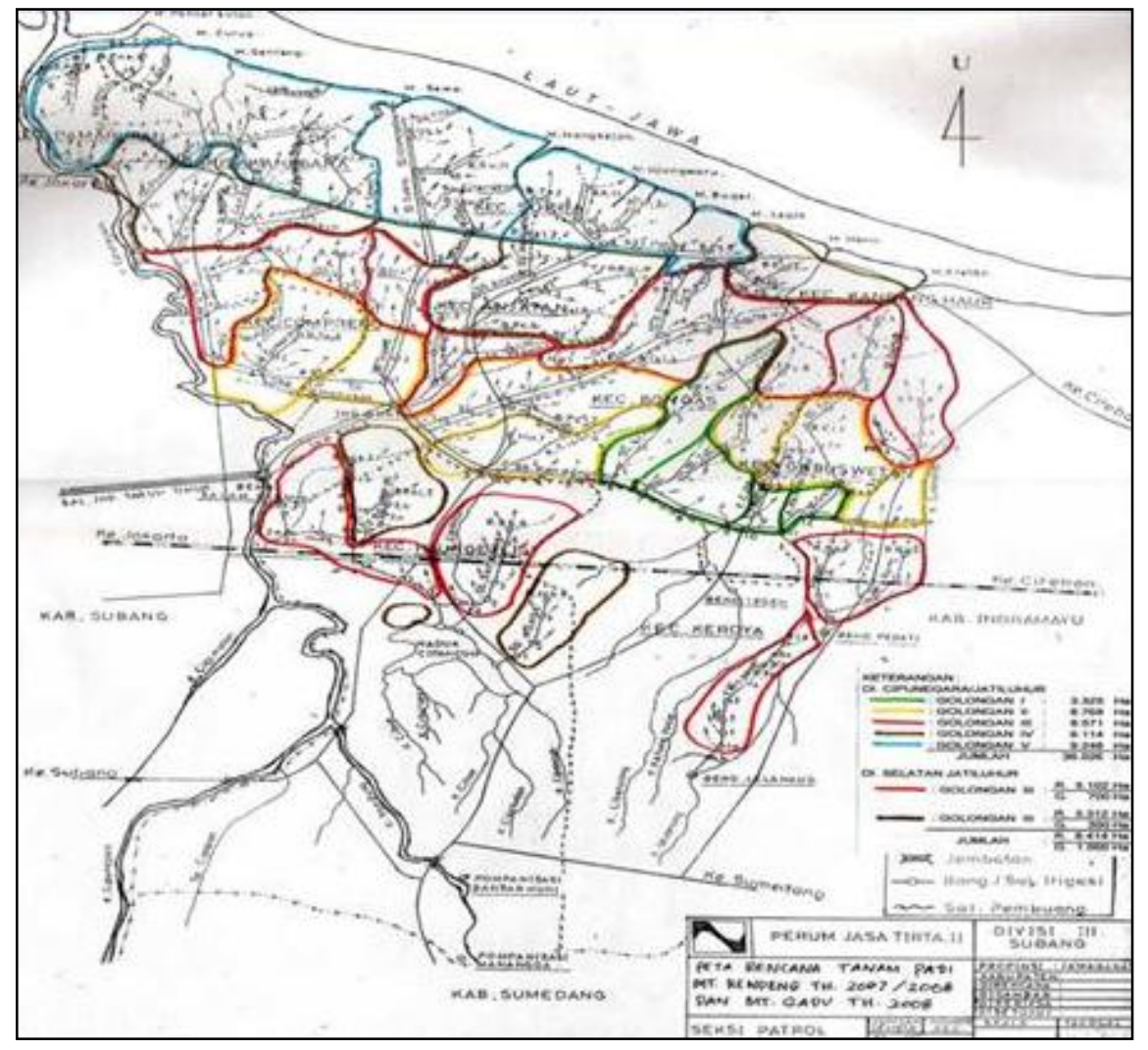

Figure 1 Map of Group Air in the Indramayu Regency (PJT II Service Area)

The operation and maintenance of the main and secondary canals were responsibilities by the local government while the tertiary canals were managed by farmer groups. The average conditions for operation of the main and secondary canals were relatively poor because of the minimum maintenance (rehabilitation cost high) and the age (more than 50 years) as well as high seepage and percolation losses (averaged about 20\%). In the diversion structure have not equipped with meter devices and the leakage in the gates relatively high so that the water could not control and also water is usually run continuously to the sea. In this conditions, the areas in the upstream (head section) received more water whereas the downstream (tail section) often inadequate in water supply (high number of stress-day). 
Irrigation system in the humid tropics designed primarily for rice cultivation probably require greater management inputs in the dry season than systems where rice is not a major component of the cropping pattern.

There are two reasons for this : (1) hydraulic factor related to the design of rice based system that have to cater for very large variations in discharge between wet and dry season and (2) variability of dry season demand, both in time throughout the season and within the system at any moment in time. The dry season represents a totally different case : water is generally scarcest physical resource so that management shortfalls will be immediately reflected in decreased production either because water is insufficient to meet demand or because of inequity in deliveries ( Murray-Rust 1990).

Principally there was five group system in the PJT II irrigation service area, for the group I, irrigation water entry to the farmers field were start on the first October, in the mid October for group II, then the first November for group III, for group IV in the mid November and the last for group $\mathrm{V}$ the irrigation water was entry in the first Desember.

Theoritically in the group I and II there were 9-10 irrigation period, so these areas could be planted by two rice crops followed by secondary crop (such as mungbean, soybean and string bean), but the facts in the farmers fields indicated that these areas has only be grown two rice crops in a year with the pattern rice-rice-fallow. The repairing of the main and secondary canals were usually done during September so these canals without irrigation water (dry period).

The water crisis or serious water shortage has generally occurred for the group III and IV. In these group, only the one rice crop (wet season crop) successfully was grown and for the dry season rice crop often suffered by pest and diseases or drought. There was quite difference in grain yield in the group I and II when compared with the group III and IV. The average grain yield were ranged from 5-7 t/ha for group I and II while the group III and IV had the average grain yield ranged between 3-4 t/ha. 


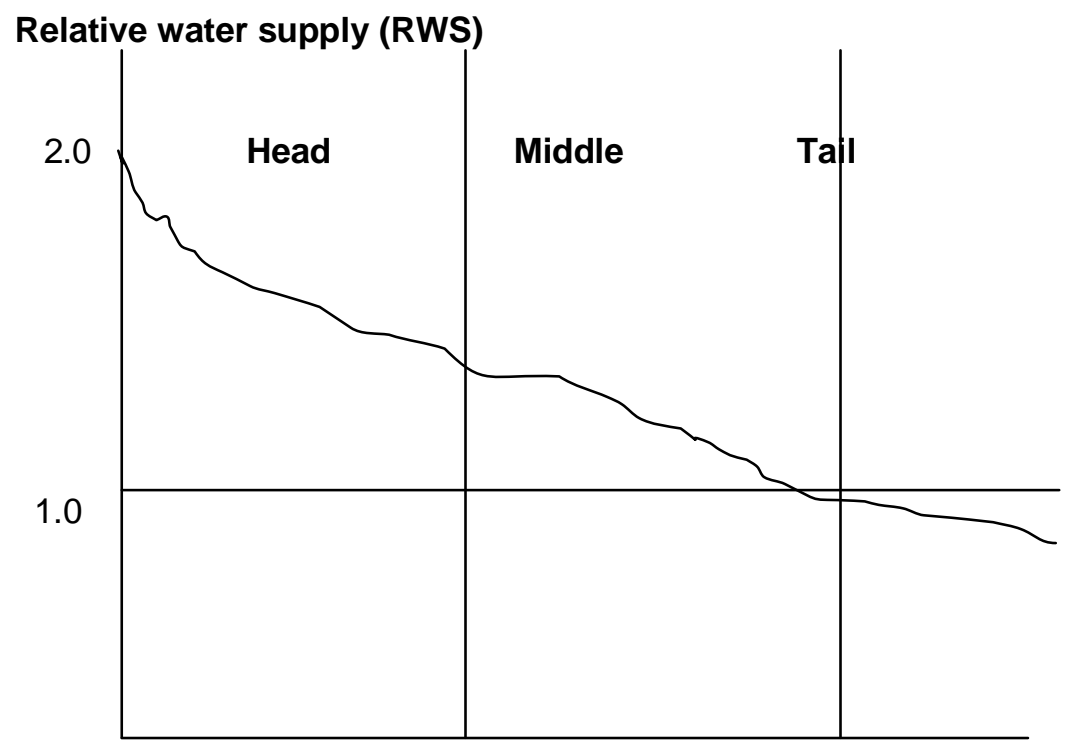

Figure 2 The pattern of the relative water supply at tertiary level

Most farmers the PJT II irrigation area traditionally practiced continuous flowing method with the depth of standing water above $10 \mathrm{~cm}$ so the irrigation efficiency ranged from $60-70 \%$ at farmers' level. In spite of that the lower of irrigation efficiency might be caused by the minimum knowledge of farmers about water management technique, some farmers made illegal or damaged the canal and other factor it has not yet established water user institution at farmers level. The conditions of tertiary canal were more poor than the main and secondary canals because of water losses were high above 15\% (mostly clay canal or without lining)maintaining of the canal by farmers were very low intensity, capital, coordination of farmers with local government very weak and sometimes occurs farmers conflicts.

It is generally was done rotation among turnouts (secondary canal receive irrigation water twice in a week). When the discharge in the secondary canal was decreased to $<40 \%$ of the normal discharge and it will be implemented "gilir giring" or irrigation with 3 days interval among farmer fields and when the discharge dropped to the $<60 \%$ of the normal discharge, it will be implemented "gilir glontor" or irrigation with 6 days interval among farmer fields. With rotation of irrigation water, the average grain yields were ranged from 4 to 5 t/ha.

Rotational schedules have to be effectively implemented if equity objectives are to be met. When managing the system for production objectives, it is important to know what the pattern of demand is at any moment in time. This require an effective method of collecting information on 
cropped area and crop type within each tertiary block. A major constraint is that demand varies greatly. Within a tertiary block there may be a whole range of different crops, each with its own specific pattern water requirements and with different irrigation scheduling needs, so that is relatively expensive to determine what the actual demand is for each block.

The water saving through the alternate wetting and drying (AWD) irrigation technique actually can be practiced by farmers in the upstream (with relative water supply above 1.0) so therefore : (a) turnaround time shorten, (b) to minimize irrigation water losses in the canal and also in farm fields particularly for the upstream area (c) irrigation water efficiency or water productivity in the service area improved, (d) to increase cropping intensity (rice-rice- non rice), (e) to hasten transplanting so escape from the drought/pest attacking for downstream areas.

\section{Efficiency of Water Use at Farmers' Level}

Until currently most farmers have practiced the continuous flowing method with the depth of standing water above $10 \mathrm{~cm}$ and irrigation period more than $70 \%$ of the days irrigation (75 days). With this technique resulted in the soil was frequently wet (anaerobic condition), perched water table closer to the soil surface, most roots did not develop normally and sometimes more roots died at flowering or poor nutrient absorption efficiency, irrigation water consumption higher, abundance in pest or diseases and grain yield lower.

The average irrigation water consumptions from transplanting to harvest by most the farmers during dry season were ranged from $13,000 \mathrm{~m}^{3} /$ ha to $15,000 \mathrm{~m}^{3} / \mathrm{ha}$, however, the recommendation of irrigation water requirement by the PJT II was $12,000 \mathrm{~m}^{3} / \mathrm{ha}$. With the average of the grain yield was $6,000 \mathrm{~kg} / \mathrm{ha}$, so, the water use efficiency or water productivity was $6,000 \mathrm{~kg} / 12,000 \mathrm{~m}^{3}$ or $0,5 \mathrm{~kg} / \mathrm{m}^{3}$.

As long as discharges are more than $60-70 \%$ of designed operating discharge, head discharge relationship are more or less stable and there should not normally be problems in operating the systems under continuous flow. However, once discharge falls below this level it becomes necessary to change from continuous flow to some form of rotational irrigation because head discharge relationship at division structure will change. Most rice based irrigation systems are designed to have the capacity to deliver sufficient water to meet maximum demand. At tertiary level this maximum demand was normally the range from 1.3 to $1.5 \mathrm{l} / \mathrm{sec} / \mathrm{ha}$. The main canals frequently have to have a maximum capacity of about 1.8 to $2.0 \mathrm{l} / \mathrm{sec} /$ ha (Murray-Rust, 1990). 
The low water use efficiency were caused particularly by lower grain yield and or higher water consumption. Reducing of irrigation water consumption by the farmers directly was rather difficult than improving of the grain yield. Nowadays IR64 variety was replaced by Ciherang variety which have a moderate tolerant to drought and stable in grain yield under varies level of water supplies. Actually, under the physical soil and hydrological conditions in the PJT II irrigation service area, maintaining the soil saturation condition during certain growth stages (vegetative and ripening stages) did not decrease grain yield even some times the yield enhanced because of aeration status in the root zone improved. Non submerged more than one week, the soil will become cracks and surface soil will be compacted and the roots growth would inhibited and the yields were lowered.

\section{Strategies of Water Saving for Lowland Rice}

Many techniques of the water saving for lowland rice cultivation have already conducted in the experimental site and also at farmers' field. These techniques were includes : a) The pattern of water requirement of lowland rice; b) effect of soil moisture stress on the yield of high yielding variety (HYV ), c) Yield response of lowland rice to interval of irrigation and total water consumption,d) SRI experiment and e) Interactions of type of varieties, plant spacing and $\mathrm{N}$ fertilizer management based on SSNM under AWD and continuous flooding conditions.

a) The pattern of water requirement of lowland rice

The actual water requirement at farmers' fields were measured by the sloping gauge (seepage and percolation) and plus actual evapotranspirations (ETa) which was obtained from the estimation of potential (ETp) with modified Penman method multiplied by crop coefficient $(\mathrm{kc})$.

Pattern of water requirement for early maturing variety (Cikapundung variety) was 6.3 $\mathrm{mm} /$ day $(0.73 \mathrm{It} / \mathrm{sec} / \mathrm{ha})$ from transplanting to panicle initiation then increased to $7.4 \mathrm{~mm} /$ day ( $0.86 \mathrm{It} / \mathrm{sec} / \mathrm{ha}$ ) from panicle initiation to $50 \%$ flowering stage and peaked at $50 \%$ flowering to grain filling with $8.4 \mathrm{~mm} /$ day $(0.97 \mathrm{lt} / \mathrm{sec} / \mathrm{ha})$ and decreased to $7.6 \mathrm{~mm} /$ day $(0.88 \mathrm{lt} / \mathrm{sec} / \mathrm{ha})$ at ripening stage (Table 1). For late maturing variety such as Cisadane variety (125 days) the pattern of the daily water requirement was similar to Cikapundung variety but the peaked was 8.8 $\mathrm{mm} /$ day (1.02). Both varieties had the same maximum daily water requirement that occurred at $50 \%$ flowering until grain filling. Accumulation of water requirement of the Cisadane variety was higher than Cikapundung variety. 
Table 1 Average daily water requirement of the lowland rice with different maturity under various growth stages at farmers' level in the PJT II service area. DS 2004

\begin{tabular}{|c|c|c|c|c|c|}
\hline \multirow[b]{3}{*}{ Village } & \multirow[b]{3}{*}{ Variety } & \multicolumn{4}{|c|}{ Growth stages } \\
\hline & & & Panicle & Flowering & \\
\hline & & $\begin{array}{l}\text { Transplanting- } \\
\text { panicle initiation }\end{array}$ & $\begin{array}{c}\text { initiation- } \\
\text { flowering } \\
50 \%\end{array}$ & $\begin{array}{l}50 \% \text { - grain } \\
\text { filling }\end{array}$ & Ripening \\
\hline Tanjungrasa kidul & Cikapundung & $6.3(0.73)$ & $7.4(0.86)$ & $8.4(0.97)$ & $7.6(0.88)$ \\
\hline Tanjungrasa kaler & Cisadane & $6.3(0.73)$ & $7.6(0.88)$ & $8.8(1.02)$ & $7.4(0.86)$ \\
\hline Kondang & Cisadane & $6.6(0.78)$ & $7.4(0.86)$ & $8.8(1.02)$ & $7.5(0.87)$ \\
\hline & IR54 & $6.5(0.75)$ & $7.5(0.87)$ & $8.0(0.93)$ & $7.3(0.85)$ \\
\hline
\end{tabular}

Source : Setiobudi (2005)

Number in parenthesis indicate It/sec/ha

The Cisadane variety had higher average daily water requirement than Cikapundung variety, this probably the Cisadane variety had the higher leaf area and transpiration rate while the different among the villages were not much change the water requirements substantially. Three villages had almost the same soil texture and hydrological conditions so that the amount of daily water requirement were similar.

From this experiment could be concluded that varietal types were not important in the determining or calculating of the daily discharge of irrigation however, late maturing variety have suitable to develop in the group I and II which have long water availability.

b) Effect of soil moisture stress on the yield of high yielding variety (HYV)

Yield of the IR64 was $48.1 \mathrm{~g} /$ pot under continuously flooded at $3 \mathrm{~cm}$ depth (Table 2). The soil moisture stress at -0.5 bar at various growth stages were significantly reduced grain yield. The greatest reduction of yield was $29.5 \%$ relative to the yield of the soil flooded at $3 \mathrm{~cm}$ depth continuously when soil moisture imposed during late reproductive stage (heading to full of flowering). With continuously flooded treatment, the average yield was $48.1 \mathrm{~g} / \mathrm{pot}$ and of 33.9 $\mathrm{g} /$ pot under soil moisture stress from heading to full of flowering stage. 
Table 2 The effects of moisture stress at various growth stages on the yield of IR64 variety. Sukamandi.

\begin{tabular}{lcc}
\hline \multicolumn{1}{c}{ Soil moisture stress treatment } & $\begin{array}{c}\text { Grain yield } \\
\text { (g/pot) }\end{array}$ & Index \\
\hline Flooded at $3 \mathrm{~cm}$ depth continuously & $48.1 \mathrm{a}$ & - \\
\hline Vegetative (10 DAT - panicle initiation) & $39.6 \mathrm{~b}$ & 17.7 \\
\hline Panicle initiation - heading & $38.9 \mathrm{~b}$ & 29.5 \\
\hline Heading to full of flowering & $33.9 \mathrm{c}$ & 15,75 \\
\hline Full flowering $100 \%$ to grain filling & $41.5 \mathrm{~b}$ & 59,29 \\
\hline Transplanting to 10 DBH & $19.6 \mathrm{~d}$ & \\
\hline
\end{tabular}

From this experiment implied that under limiting water supply, irrigation should be focus on the flooded condition from heading to full of flowering stage and the soil kept saturation condition for other growth stages. Under moderate soil moisture stress, IR64 variety was relative sensitive during late reproductive stage (haeding to full of flowering).

In the development of irrigation water saving technique, the sensitivity of variety to moisture stress and critical growth stage to moisture stress should be considered. This is important is related to achieve higher yield as well as water productivity. The decreasing of yield by soil moisture stress were caused by the higher sterility, lower in the 1,000 grain weight and ripened of grains (percentage of filled grain). High yielding variety such as IR64 variety was consumed much water because of this variety had a shallow root systems (high tillering type).

c) Yield response of lowland rice to interval of irrigation and total water consumption

The yield responses of the Way Apo Buru, Memberamo and Ciliwung varieties to days interval irrigation were carried out at farmers' field at Indramayu regency during the 2003 dry season. The site was characterized by poor drainage, clay soil texture and low permeability. During growing period, the rainfall supply was $90.5 \mathrm{~mm}$ and occurred during reproductive stage. The three days interval irrigation was a critical level for the achieving of higher yield. The average yield was 5.2 t/ha under continuously flooded at $3 \mathrm{~cm}$ depth with the total water consumption was $595 \mathrm{~mm}$. The yield was not significantly decreased of $4.9 \mathrm{t} / \mathrm{ha}$ when compared to the yield of continuously 
Didiek Setiobudi dan Hasil Sembiring

flooded. At 3 days irrigation interval, the average of total water consumption was about 425 $\mathrm{mm}$. The water productivity with respect irrigation input was higher in the 3 days irrigation interval about $11.7 \mathrm{~kg} / \mathrm{ha} . \mathrm{mm}$. A 5 days irrigation interval the yield and also water productivity decreased, it might be caused by the crop suffered by moisture stress (Table 3 ).

Table 3 Average of yield, total water consumption and water productivity at Indramayu. DS 2003

\begin{tabular}{cccc}
$\begin{array}{c}\text { Water application } \\
\text { methods }\end{array}$ & $\begin{array}{c}\text { Yield } \\
(\mathrm{kg} / \mathrm{ha})^{*}\end{array}$ & $\begin{array}{c}\text { Total water } \\
\text { consumption } \\
(\mathrm{mm})^{* *}\end{array}$ & $\begin{array}{c}\text { Water productivity } \\
(\mathrm{kg} / \mathrm{ha} \cdot \mathrm{mm})\end{array}$ \\
\hline a1: Flooded at $3 \mathrm{~cm}$ & $5.260,0 \mathrm{a}$ & 595,0 & 9.20 \\
\hline a2 : 3 days interval & $4.950,0 \mathrm{a}$ & 425,0 & 11.7 \\
\hline a3 : 5 days interval & $4.610,0 \mathrm{~b}$ & 490,0 & 9.4
\end{tabular}

Means followed by a common letter at the same column are not significantly different by DMRT at $5 \%$ level

* Average yields of the Memberamo, Way Apo Buru and Ciliwung varieties. Rainfall from transplanting to harvest $90.5 \mathrm{~mm}$

** Water consumptions were measured by $\mathrm{V}$-notch

d) SRI Experiment

The SRI irrigation was avoid keeping of paddy soil saturated during the vegetative growth period (introduce some soil aeration) and then maintain continuously flooded conditions during the reproductive and grain filling stages to promote better plant growth and increase grain yield. With SRI model, the farmers are practiced either AWD or non flooding (NF) irrigation during the period of tillering until panicle initiation after which the soil kept the plot continuously flooded until 10-14 d before grain maturity and harvesting.

The field experiment was carried out at farmers' filed at Bekasi regency, West Java to study irrigation based on the original SRI (used compost only) and modified irrigation of the SRI (plus $\mathrm{N}$ fertilizer based on LCC readings) and irrigation by farmers practices (Table 4). The average grain yields of the SRI rice cultivation (original model) were lowest about $5.2 \mathrm{t} /$ ha with the total water consumption was $395.8 \mathrm{~mm}$ and the water productivity was $13.1 \mathrm{~kg} / \mathrm{ha} . \mathrm{mm}$. The higher yields and water productivity were obtained from the modified irrigation of the SRI with the pattern of 2 $\mathrm{cm}-80 \%$ field saturation (vegetative stage), $1 \mathrm{~cm}-80 \%$ field saturation 
(reproductive stage) and field saturation to the $80 \%$ of the field saturation plus,fertilizer $\mathrm{N}$ based on LCC reading about $6.6 \mathrm{t} / \mathrm{ha}$ and water productivity was $17.9 \mathrm{~kg} / \mathrm{ha} . \mathrm{mm}$ and the pattern of field saturation $-80 \%$ of field saturation (vegetative stage), then $2 \mathrm{~cm}$ to the $80 \%$ of field saturation (reproductive stage) and followed by field saturation to $80 \%$ field saturation (ripening stage) plus fertilizer N based on LCC readings gave 6.8 t/ha with the water productivity was $13.9 \mathrm{~kg} / \mathrm{ha} . \mathrm{mm}$. The yield of the farmers' practice was about $5.5 \mathrm{t} / \mathrm{ha}$ and the water productivity was 9.7 $\mathrm{kg} / \mathrm{ha} . \mathrm{mm}$. With the SRI rice cultivation original model, the yield was low because of low of number of tiller/hill, number of panicle /hill, number of spikelet/panicle and weight 1,000 grains. The low yield resulted in decreasing in water productivity. The SRI model was not productive to develop in the lowland conditions, heavy soil and with poor drainage. Application compost in the SRI model of rice cultivation did not improve soil fertility status markedly in the short term period.

Table 4 Average of grain yield, total water consumption and water productivity of Sintanur variety with SRI rice cultivation. Bekasi. WS 2006/2007

\begin{tabular}{|c|c|c|c|}
\hline Treatment & Yield (kg/ha; mc : 14\%) & $\begin{array}{c}\text { Total water } \\
\text { consumption }(\mathrm{mm})\end{array}$ & $\begin{array}{l}\text { Water productivity } \\
(\mathrm{kg} / \mathrm{ha} . \mathrm{mm})\end{array}$ \\
\hline $\begin{array}{l}\text { A : FS-80\% FS (veg. } \\
\text { stage) ; } 2 \mathrm{~cm}-80 \% \text { FS; } \\
\text { FS- } 80 \% \text { FS (RS) - plus } \\
10 \text { t/ha compost }\end{array}$ & $5,202.5 \mathrm{~b}$ & 395.8 & 13.1 \\
\hline $\begin{array}{l}\mathrm{B}: 2 \mathrm{~cm}-80 \% \text { FS } \\
\text { (veg.stage); } 1 \mathrm{~cm}-80 \% \\
\text { FS and FS-80\% FS } \\
\text { (RS) plus } \mathrm{N} \text { fertilizer } \\
\text { based on LCC }\end{array}$ & $6,579.3 \mathrm{a}$ & 366.9 & 17.9 \\
\hline $\begin{array}{l}\text { C : FS-60\% FS (VS); } 2 \\
\mathrm{~cm}-\mathrm{FS}(\mathrm{R}) ; \mathrm{FS}-80 \% \mathrm{FS} \\
\text { (RS) plus } \mathrm{N} \text { fertilizer } \\
\text { based LCC readings }\end{array}$ & $6,828.9 \mathrm{a}$ & 492.1 & 13.9 \\
\hline $\begin{array}{l}\text { D : } 2 \mathrm{~cm}-80 \% \text { FS (VS); } \\
2 \text { cm-FS (R); FS-80\% } \\
\text { FS (RS) plus } 10 \text { t/ha } \\
\text { compost and foliar } \\
\begin{array}{ll}\text { application } & \text { (local } \\
\text { microorganism) }\end{array}\end{array}$ & $6,000.8 \mathrm{ab}$ & 548.9 & 10.9 \\
\hline $\begin{array}{l}\text { E : } 2 \mathrm{~cm}-60 \% \text { FS (VS); } \\
2 \text { cm-FS (R); FS-80\% } \\
\text { FS (RS) plus } 10 \text { t/ha } \\
\text { compost and foliar } \\
\begin{array}{l}\text { application of local } \\
\text { microorganism }\end{array}\end{array}$ & $5,241.5 b$ & 487.8 & 10.7 \\
\hline Farmers' practiced & $5,537.5$ & 573.3 & 9.7 \\
\hline
\end{tabular}

Source : Setiobudi and Sukrasno (2007)

Means followed by a common letter at the same column are not significantly different by DMRT at $5 \%$ level. FS : field saturation, VS : vegetative stage, $R$ : reproductive stage $R S$ : ripening stage 
The irrigation practiced of the SRI was 55\% less irrigation water than the conventional practice of continuous submergence during all periods. The productivity of water (calculated as grain yield per unit of irrigation water applied) for SRI was $0.30 \mathrm{~kg} / \mathrm{m}^{3}$ ) than for continuous flooding $\left(0.13 \mathrm{~kg} / \mathrm{m}^{3}\right)$ on the highly permeable (seepage +percolation $>5 \mathrm{~cm} /$ day) terraced paddies (McHugh, et al., 2002).

In Madagascar, the average SRI yield of $6.4 \mathrm{t} /$ ha was significantly higher than the $3.4 \mathrm{t} / \mathrm{ha}$ observed on conventional plots. At all locations, grain yields for SRI were $70-90 \%$ higher than conventional yields. The yield of 7.4 t/ha was produced with AWD irrigation and SRI rice cultivation practices.

In China, the total water input (rainfall + irrigation) ranged from 569 to $934 \mathrm{~mm}$ of which 354 $\mathrm{mm}$ was rainfall. The daily percolation rates ranged from 0.2 to $1.4 \mathrm{~mm} /$ day, averaging 0.7 $\mathrm{mm} /$ day. Summed over the whole season, percolation loss was $73 \mathrm{~mm}$ in continuous flooding and $62 \mathrm{~mm}$ in alternate wetting and drying. There was no significant difference in percolation and seepage losses between the two varieties. The low percolation rate are attributed to the shallow groundwater table. Continuous flooding had significantly the highest seepage loss.

The total water productivity $\left(\mathrm{WP}_{\mathrm{I}+\mathrm{R}}\right)$ for hybrid rice ranged from 0.8 to $2.4 \mathrm{~kg} / \mathrm{m}^{3}$ whereas the irrigation water productivity $\left(\mathrm{WP}_{\mathrm{I}}\right)$ ranged from 1 to $16 \mathrm{~kg} / \mathrm{m}^{3}$. With a water table close to the soil surface, the roots could extract water directly from the groundwater. Among the four water treatments, PRF had the highest $W P_{1+R}$ and $W P_{1}$ and $A W D$ had the lowest.

Water saving irrigation, especially flush irrigation and partially rainfed systems can significantly reduce the amount of irrigation compared with farmers' practices without affecting rice yield. This implies that there is a possibility for irrigation system management to reduce the amount of water diverted to rice at the study site.

These findings and their implication were site specific and care must be taken in extrapolation. In larger fields, the irrigation time is longer, which may result in larger seepage and deep percolation losses. At our site, the groundwater tables were very shallow and the rice plants could directly take up groundwater to meet their demand for transpiration. More study is needed on the interaction between irrigation and groundwater table depth before recommendation for large scale application of water saving irrigation techniques can be made. The shallow groundwater tables at our experimental sites may be the result of continuously flooded water surrounding rice fields that recharge the groundwater through deep percolation. With the wide scale adoption of water saving 
irrigation techniques, the groundwater tables may go down because of less groundwater recharge from the rice field. Furthermore, seepage from unlined irrigation canals may reduce seepage and effects on groundwater tables (Lu, et al., 2002).

e) Interactions of type of varieties, plant spacing and $\mathrm{N}$ fertilizer management based on SSNM under AWD and continuous flooding conditions.

The yield responses of the hybrid, inbred and NPT line of lowland rice were conducted at the Sukamandi experimental farm during the DS 2008 and WS 2008/2009. The site was characterized as follows : $15 \mathrm{~m}$ above sea level, clay soil texture, $\mathrm{pH} 5.5$, total $\mathrm{N}: 0.15 \%$ (deficient), organic-C : 1,35\% (low), shallow perched water table (poor drainage), rainfall supply very erratic and less than $50 \mathrm{~mm}$ per month during dry season.

The effects of varietal types, plant spacing and rate of $\mathrm{N}$ with high and low of $\mathrm{N}$ at early vegetative stage based on site specific nutrient management (SSNM) on yield component under alternate wetting and drying during DS 2008 is presented in the Table 5. The hybrid rice (Rokan variety) had the highest number of panicle per hill and weight of 1,000 grains and the NPT rice (BP360) had the lowest of the 1,000 grain weight and percentage of filled spikelet. Ciherang variety had the lowest number of panicle per hill, spikelet number per panicle, spikelet number per hill as well as spikelet number $/ \mathrm{m}^{2}$. Spacings of $25 \mathrm{~cm} \times 25 \mathrm{~cm}$ was significantly increased number of panicle/hill, number of spikelet/hill, number spiklelet per panicle but it was reduced number spikelet $/ \mathrm{m}^{2}$. Nitrogen management based on SSNM with high $\mathrm{N}$ supply during early vegetative stage was not significantly affected all yield component characteristics.

The NPT line had a poor grain filling rate so that the percentage filled spikelet and weight 1,000 grain weight. Hybrid rice had more $\mathrm{N}$ absorption than Ciherang variety and NPT line during reproductive stage therefore it had the superior of yield component. Under alternate wetting and drying, the differentiation of spikelet of the Ciherang variety was significantly decreased. With wider spacing of $25 \mathrm{~cm} \times 25 \mathrm{~cm}$ there was a sufficient space for tillering process and reduction of competitive of nutrient uptake so panicle and spikelet formations improved. 
Table 5 Yield components of the hybrid, inbred and new plant type line of rice with different plant spacing and nitrogen fertilizer application under alternate wetting and drying. Sukamandi. DS 2008

\begin{tabular}{ccccccc}
\hline \multirow{2}{*}{ Treatment } & Panicle & Spikelet & Spikelet & Spikelet & Wt. 1,000 Filled spikelet \\
& (no/hill) & $($ no./panicle $)$ & $($ no./hill $)$ & $\left(\right.$ no. $\left./ \mathrm{m}^{2}\right)$ & grain $(\mathrm{g})$ & $(\%)$ \\
\hline
\end{tabular}

Variety

(V)

\begin{tabular}{|c|c|c|c|c|c|c|c|}
\hline Hybrid & (v1) & $15,9 \mathrm{a}$ & $146,5 \mathrm{a}$ & $2340 a$ & $46449 a$ & $28,0 \mathrm{a}$ & $92,0 \mathrm{a}$ \\
\hline NPT line & (v2) & $14,1 \mathrm{~b}$ & $149,0 \mathrm{a}$ & $2099 a$ & $41816 a$ & $26,6 \mathrm{~b}$ & $79.3 \mathrm{~b}$ \\
\hline Ciherang & (v3) & $14,9 \mathrm{~b}$ & $122,1 \mathrm{~b}$ & $1820 \mathrm{~b}$ & $36331 \mathrm{~b}$ & $28,3 \mathrm{a}$ & $92,2 \mathrm{a}$ \\
\hline Spacing & $(\mathrm{P})$ & & & & & & \\
\hline$(20 \times 20) \mathrm{cm}$ & (p1) & $13,3 \mathrm{~b}$ & $136,5 \mathrm{~b}$ & $1811 \mathrm{~b}$ & $45278 \mathrm{a}$ & $27,7 \mathrm{a}$ & $87,7 \mathrm{a}$ \\
\hline$(25 \times 25) \mathrm{cm}$ & (p2) & $16,7 \mathrm{a}$ & $142,0 \mathrm{a}$ & $2362 \mathrm{a}$ & 37786 b & 27,6 a & $88,0 \mathrm{a}$ \\
\hline 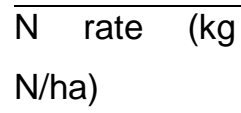 & $(\mathrm{N})$ & & & & & & \\
\hline Low (30) & (n1) & $15,1 \mathrm{a}$ & $139,2 \mathrm{a}$ & $2101 a$ & $41933 \mathrm{a}$ & $27,8 \mathrm{a}$ & $88,6 \mathrm{a}$ \\
\hline High (60) & (n2) & $14,9 \mathrm{a}$ & $139,2 \mathrm{a}$ & $2072 a$ & $41132 \mathrm{a}$ & $27,5 \mathrm{a}$ & $87,1 \mathrm{a}$ \\
\hline
\end{tabular}

Means followed by a common letter at the same column are not significantly different by DMRT at $5 \%$ level.

Under continuously flooded at $3 \mathrm{~cm}$ from 10 days after transplanting to 7 days before harvest, the hybrid rice (Rokan variety) had the highest number of panicle per hill. The hybrid and NPT line rice had greater number spikelet/panicle, number spikelet/hill and number spikelet $/ \mathrm{m}^{2}$, however, the NPT line (BP360) had the lowest of the percentage of filled spikelet and weight 1,000 grains. The $\mathrm{N}$ management based on SSNM with low and high rate in the early vegetative stage were not significantly affected all yield component. Plant spacing of $25 \mathrm{~cm} \times 25 \mathrm{~cm}$ had a greater number of panicle per hill and also number spikelet per hill (Table 6).

The hybrid rice had a greater $\mathrm{N}$ absorption rate during vegetative stage, so the number of panicle/hill increased rapidly. Although without soil moisture stress, the 1,000 grain weight and percentage of filled spikelet were lower in the NPT line (BP360). This was probably caused by genetic factor rather than cultural practices. Decreasing in percentage of filled spikelet resulted in the weight 1,000 grain decreased. 
The plant spacing of $25 \mathrm{~cm} \times 25 \mathrm{~cm}$ was beneficial for the panicle production under both alternate wetting and drying and continuous flooding at $3 \mathrm{~cm}$ depth consistently. This was probably caused by increasing in $\mathrm{N}$ and $\mathrm{P}$ uptake during vegetative stage because of the higher in absorption of solar radiation.

Table 6 Yield components of the hybrid, inbred and new plant type line of rice with different plant spacing and nitrogen fertilizer application under continuous flooding at $\mathbf{3} \mathbf{~ c m}$ depth. Sukamandi. DS 2008

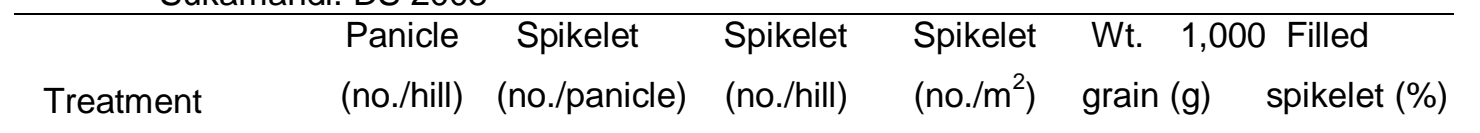

\begin{tabular}{llllllll}
\hline Variety & $(\mathrm{V})$ & \multicolumn{1}{c}{} \\
\hline Hybrid & $(\mathrm{v} 1)$ & $16.9 \mathrm{a}$ & $146.2 \mathrm{a}$ & $2467 \mathrm{a}$ & $49456 \mathrm{a}$ & $28.1 \mathrm{a}$ & $91.1 \mathrm{a}$ \\
\hline NPT line & $(\mathrm{v} 2)$ & $14.9 \mathrm{~b}$ & $145.2 \mathrm{a}$ & $2166 \mathrm{a}$ & $43491 \mathrm{a}$ & $26.8 \mathrm{~b}$ & $80.1 \mathrm{~b}$ \\
\hline Ciherang & $(\mathrm{v} 3)$ & $14.8 \mathrm{~b}$ & $121.8 \mathrm{~b}$ & $1792 \mathrm{~b}$ & $35876 \mathrm{~b}$ & $28.8 \mathrm{a}$ & $95.1 \mathrm{a}$ \\
\hline N rate & & & & & &
\end{tabular}

$\mathrm{N}$ rate

(kg N/ha)

\begin{tabular}{llllllll}
\hline Low (30) & $(\mathrm{n} 1)$ & $15.5 \mathrm{a}$ & $137,2 \mathrm{a}$ & $2127 \mathrm{a}$ & $42671 \mathrm{a}$ & $27,9 \mathrm{a}$ & $89.0 \mathrm{a}$ \\
\hline High (60) & $(\mathrm{n} 2)$ & $15.6 \mathrm{a}$ & $138,4 \mathrm{a}$ & $2156 \mathrm{a}$ & $43211 \mathrm{a}$ & $28,0 \mathrm{a}$ & $88.4 \mathrm{a}$ \\
\hline Spacing & $(\mathrm{P})$ & & & & & & \\
\hline$(20 \times 20) \mathrm{cm}$ & $(\mathrm{p} 1)$ & $14.1 \mathrm{~b}$ & $136.9 \mathrm{a}$ & $1928 \mathrm{~b}$ & $48207 \mathrm{a}$ & $27.8 \mathrm{a}$ & $88.8 \mathrm{a}$ \\
\hline$(25 \times 25) \mathrm{cm}$ & $(\mathrm{p} 2)$ & $17.0 \mathrm{a}$ & $138.6 \mathrm{a}$ & $235.5 \mathrm{a}$ & $37675 \mathrm{~b}$ & $28.1 \mathrm{a}$ & $88.6 \mathrm{a}$ \\
\hline
\end{tabular}

Means followed by a common letter at the same column are not significantly different by DMRT

Yield components under alternate water treatment are varied (Table 7 and 8). In the wet season (WS) 2008/2009, average of the number of panicle/hill, weight 1,000 grains, number spikelet/panicle and percentage of filled spikelet of the hybrid rice (Rokan variety) and NPT line (BP360) was significantly higher than Ciherang variety. The plant spacing of $25 \mathrm{~cm} \times 25 \mathrm{~cm}$ had higher number of panicle/hill and number spikelet per hill under alternate wetting and drying. The management of $\mathrm{N}$ fertilizer based on SSNM was not significantly affected all yield components (Table 7). The efficiency of the absorption of solar radiation of the rice canopy was higher in the $25 \mathrm{~cm} \times 25 \mathrm{~cm}$ spacing than the $20 \mathrm{~cm} \times 20 \mathrm{~cm}$. Increasing in efficiency of absorption of solar radiation, it would be increased the number of panicle/hill and number spikelet/hill even with alternate wetting and drying (AWD) irrigation method during wet season. 
It seems that Ciherang variety was not suitable to develop for the wet season cropping because of it's has lower in the number of spikelet/panicle and weight 1,000 grains. this might be caused by lower fertilization a nd rate of grain filling under alternate wetting and drying. The grain filling process of the NPT line was might be controlled by genetic factor and imbalance between sink capacity and source activity.

Table 7 Yield components of the hybrid, inbred new plant type line of rice with different plant spacing and nitrogen fertilizer application under alternate wetting and drying. Sukamandi. WS 2008/2009

\begin{tabular}{|c|c|c|c|c|c|c|}
\hline \multirow[b]{2}{*}{ Treatment } & \multicolumn{5}{|c|}{ Yield component } & \multirow[b]{2}{*}{$\begin{array}{l}\text { Spikelet } \\
\left(\text { no. } / \mathrm{m}^{2}\right)\end{array}$} \\
\hline & $\begin{array}{l}\text { Panicle } \\
\text { (no./hill) }\end{array}$ & $\begin{array}{l}\text { Wt.1,000 } \\
\text { grains } \\
\text { (g) }\end{array}$ & $\begin{array}{c}\text { Filled } \\
\text { grains } \\
\text { grailled } \\
(\%) \\
(\%)\end{array}$ & $\begin{array}{c}\text { Spikelet } \\
\text { (no./panicle) }\end{array}$ & $\begin{array}{l}\text { Spikelet } \\
\text { (no./hill) }\end{array}$ & \\
\hline \multicolumn{7}{|l|}{ Variety } \\
\hline Hybrid & $13,2 \mathrm{a}$ & $28,7 \mathrm{a}$ & 73,4 b 26,6 a & $150,0 \mathrm{a}$ & $1978 \mathrm{a}$ & $38692 \mathrm{a}$ \\
\hline NPT line $\quad$ (V2) & $13,3 \mathrm{a}$ & 28,6 a & 73,9 b $26,1 \mathrm{a}$ & $144,4 \mathrm{a}$ & $1934 \mathrm{a}$ & 37799 a \\
\hline .Ciherang (V3) & $14,2 \mathrm{a}$ & $27,4 \mathrm{~b}$ & 78,2 a 21,8 b & 128,6 b & $1834 \mathrm{a}$ & $36444 \mathrm{a}$ \\
\hline \multicolumn{7}{|l|}{ Spacing } \\
\hline$(20 \times 20) \mathrm{cm} \quad(\mathrm{P} 1)$ & $11,2 b$ & $28,3 a$ & 74,3 a 25,7 a & $139,3 \mathrm{a}$ & $1555 \mathrm{~b}$ & $38866 \mathrm{a}$ \\
\hline$(25 \times 25) \mathrm{cm} \quad(\mathrm{P} 2)$ & $16,0 \mathrm{a}$ & $28,2 \mathrm{a}$ & 76,1 a 23,9 a & $142,7 \mathrm{a}$ & $2276 \mathrm{a}$ & $36424 \mathrm{a}$ \\
\hline \multicolumn{7}{|l|}{$\mathrm{N}$ rate $(\mathrm{kg} \mathrm{N} / \mathrm{ha})$} \\
\hline Low (40) & $13,4 \mathrm{a}$ & $28,3 \mathrm{a}$ & 73,7 a 26,3 a & $140,5 \mathrm{a}$ & $1888 \mathrm{a}$ & $37288 \mathrm{a}$ \\
\hline High (70) & $13,7 \mathrm{a}$ & 28,2 a & 76,7 a 23,3 a & $141,5 \mathrm{a}$ & $1943 \mathrm{a}$ & 38002 a \\
\hline
\end{tabular}

Means followed by a common letter at the same column are not significantly different by DMRT at $5 \%$ level.

It was found that during wet season 2008/2009 and under the continuously flooding $3 \mathrm{~cm}$ depth, the Ciherang variety performed poor in term of yield component production than hybrid and NPT line rice varieties. The plant spacing of $25 \mathrm{~cm} \times 25 \mathrm{~cm}$ had just improved the number of panicle/hill and number spikelet per hill and other yield components were comparable.

The $\mathrm{N}$ management based on the SSNM with different rate of $\mathrm{N}$ at early vegetative stage was not significantly affected all yield components (Table 8). 
The Ciherang variety has seems required higher solar radiation intensity during vegetative and reproductive stage to absorbed $\mathrm{N}$ in the maximum rate to produce more panicle per hill and number of spikelet/panicle.

Table 8 Yield components of the hybrid, inbred and new plant type line of rice with different plant spacing and nitrogen fertilizer application under continuous flooding at $\mathbf{3} \mathbf{~ c m}$ depth. Sukamandi. WS 2008

\begin{tabular}{lccccccc}
\hline & \multicolumn{7}{c}{ Yield component } \\
\cline { 2 - 8 } Treatment & Panicle & 1,000 & spikelet & Unfilled & Spikelet & Spikelet & Spikelet \\
& (no./hill) & grains & $(\%)$ & spikelet & (no./panicle) & $($ no./hill) & $\left(\right.$ no. $\left./ \mathrm{m}^{2}\right)$ \\
& & $(\mathrm{g})$ & & $(\%)$ & & & \\
\hline
\end{tabular}

Varietas

\begin{tabular}{lcccccccc}
\hline Hybrid & (V1) & $14,2 \mathrm{a}$ & $28,0 \mathrm{a}$ & $75,8 \mathrm{a}$ & $24,2 \mathrm{a}$ & $142,3 \mathrm{a}$ & $2032 \mathrm{a}$ & $39831 \mathrm{a}$ \\
\hline NPT line & (V2) & $14,4 \mathrm{a}$ & $28,2 \mathrm{a}$ & $73,6 \mathrm{a}$ & $26,4 \mathrm{a}$ & $132,0 \mathrm{~b}$ & $1916 \mathrm{ab}$ & $37302 \mathrm{ab}$ \\
\hline .Ciherang & (V3) & $14,6 \mathrm{a}$ & $27,3 \mathrm{~b}$ & $76,9 \mathrm{a}$ & $23,1 \mathrm{a}$ & $127,2 \mathrm{~b}$ & $1850 \mathrm{~b}$ & $36449 \mathrm{~b}$
\end{tabular}

Plant

spacing

\begin{tabular}{lcccccccc}
\hline$(20 \times 20) \mathrm{cm}$ & $(\mathrm{P} 1)$ & $11,8 \mathrm{~b}$ & $27,8 \mathrm{a}$ & $75,8 \mathrm{a}$ & $24,2 \mathrm{a}$ & $131,2 \mathrm{a}$ & $1542 \mathrm{~b}$ & $38545 \mathrm{a}$ \\
\hline$(25 \times 25) \mathrm{cm}$ & $(\mathrm{P} 2)$ & $17,0 \mathrm{a}$ & $27,9 \mathrm{a}$ & $75,0 \mathrm{a}$ & $25,0 \mathrm{a}$ & $136,4 \mathrm{a}$ & $2323 \mathrm{a}$ & $37176 \mathrm{a}$ \\
\hline N rate (kg N/ha) & & & & & & & \\
\hline Low (40) & (N1) & $14,5 \mathrm{a}$ & $27,7 \mathrm{a}$ & $74,2 \mathrm{a}$ & $25,8 \mathrm{a}$ & $132,0 \mathrm{a}$ & $1916 \mathrm{a}$ & $37476 \mathrm{a}$ \\
\hline High (70) & (N2) & $14,3 \mathrm{a}$ & $28,0 \mathrm{a}$ & $76,6 \mathrm{a}$ & $23,3 \mathrm{a}$ & $135,7 \mathrm{a}$ & $1949 \mathrm{a}$ & $38246 \mathrm{a}$
\end{tabular}

Means followed by a common letter at the same column are not significantly different by DMRT at $5 \%$ level

Spikelet differentiation and survival also varied among varieties. Potential grain loss was due to spikelet abortion at preflowering followed by that at postflowering. Preflowering spikelet abortion was higher in IR42 than in IR50. Panicle and spikelet development took 15-18 d in IR50 and 24-31 d in IR42.

Produced the maximum yield of $5.8 \mathrm{t} / \mathrm{ha}$, yields ranging from 6.1 to $6.7 \mathrm{t} / \mathrm{ha}$ at $118 \mathrm{~kg} \mathrm{~N} / \mathrm{ha}$. Excessive vegetative growth that caused yields to decline. Yields of IR36, IR42 and IR64 in the dry and wet season were low and variable because of stem borers and stem rot also caused low yields. 
The highest yield (4.8 t/ha) was obtained with medium maturing IR. IR gave the highest yield in DS, low WS yields with were caused by infestation. Application of $150 \mathrm{~kg} \mathrm{~N} / \mathrm{ha}$ was sufficient to increase $\mathrm{N}$ uptake at harvest. The total $\mathrm{N}$ uptake of IR was similar to that of IR at 40 DAT and at flowering and harvest. On the other hand, IR had lower N uptake than IR65 at flowering. Grain yield of hybrid rice, inbred lines and NPT line at varying N rates. Severe lodging particularly tall variety with increasing of $\mathrm{N}$ rate (IRRI, 1989).

Variability in rate and duration of grain filling. The correlation between GFR and 100 grain weight was high. Grain number per panicle was significantly negatively correlated with 100 grain weight. Grain filling duration showed no significant correlation with any of the traits measured. The effect of spacing on $\mathrm{N}$ absorption as a function of $\mathrm{N}$ level. Varietal differences in $\mathrm{N}$ absorption ability were observed at tillering and were highly correlated with yield and yield components. Different $\mathrm{N}$ levels and spacing affected $\mathrm{N}$ absorption. Narrow spacing increased $\mathrm{N}$ absorption at different $\mathrm{N}$ levels such that $\mathrm{N}$ absorption at low $\mathrm{N}$ level was compensated by narrow spacing. In a short duration variety PS/N was lower under wider spacing. $\mathrm{N}$ absorption at early growth stages could be increased by narrow spacing and high basal $\mathrm{N}$ level. Spacing affected the tillering pattern and the tiller number per unit area. In young seedling and narrow spacing treatments, tillering was promoted as well as lengthened the vegetative lag phase. Narrow spacing increased the contribution of $\mathrm{N}$ to potential sink in the short duration variety by increasing the duration of the vegetative lag phase.

In general with the same of the AWD irrigation, the average grain yield for DS 2008 were ranged from $7701 \mathrm{~kg} / \mathrm{ha}$ to $8169 \mathrm{~kg} / \mathrm{ha}$ (at $\mathrm{mc}: 14 \%$ ) and it was higher than the grain yield of WS $2008 / 2009$ cropping which have ranged between $6456 \mathrm{~kg} / \mathrm{ha}$ and $7101 \mathrm{~kg} / \mathrm{ha}$. The yield performance of the DS 2008 and WS 2008/2009 with the same continuously flooded $3 \mathrm{~cm}$ depth, the average yield of DS 2008 was higher than the yield of the WS 2008/2009. The mean yield was ranged between $7892 \mathrm{~kg} / \mathrm{ha}$ and $8501 \mathrm{~kg} / \mathrm{ha}$ for the DS 2008 and was ranged from 6087 $\mathrm{kg} / \mathrm{ha}$ to $6721 \mathrm{~kg} / \mathrm{ha}$ for the WS $2008 / 2009$.

Under AWD irrigation method during the DS 2008, the average of the total water consumption was ranged from $6922 \mathrm{~m}^{3}$ to $7999 \mathrm{~m}^{3}$ and was ranged from $5876 \mathrm{~m}^{3}$ to $6358 \mathrm{~m}^{3}$ for the WS 2008/2009. Under continuously flooded at $3 \mathrm{~cm}$ depth during the DS 2008, the average of total water consumption was ranged between $8409 \mathrm{~m}^{3}$ to $9109 \mathrm{~m}^{3}$ and was ranged from 6480 $\mathrm{m}^{3}$ to $6961 \mathrm{~m}^{3}$ for the wet season 2008/2009. The AWD irrigation could saved irrigation water was ranged from $18 \%$ to $12 \%$ for DS 2008 and of $9 \%$ until $8 \%$ for the WS $2008 / 2009$. 
Table 9 Average of grain yield, total water consumption and water productivity under alternate wetting and drying. Sukamandi. DS 2008

\begin{tabular}{|c|c|c|c|c|}
\hline \multirow{2}{*}{ Treatment } & & $\begin{array}{c}\text { Yield (kg/ha; mc } \\
: 14 \%)\end{array}$ & $\begin{array}{l}\text { Total water } \\
\text { consumption }\end{array}$ & Water productivity \\
\hline & & & (m3) & $(\mathrm{kg} / \mathrm{m} 3)$ \\
\hline Variety & $(\mathrm{V})$ & & & \\
\hline Hybrid & (v1) & $8157 \mathrm{a}$ & $7736 \mathrm{a}$ & $1,08 \mathrm{a}$ \\
\hline NPT line & (v2) & $8169 a$ & $7082 \mathrm{a}$ & $1,19 a$ \\
\hline Ciherang & (v3) & $7701 \mathrm{a}$ & $7563 a$ & $1,07 \mathrm{a}$ \\
\hline Plant spacing & $(\mathrm{P})$ & & & \\
\hline$(20 \times 20) \mathrm{cm}$ & (p1) & $8071 \mathrm{a}$ & $7323 a$ & $1,13 a$ \\
\hline$(25 \times 25) \mathrm{cm}$ & (p2) & $7947 \mathrm{a}$ & 7597 a & $1,10 a$ \\
\hline Rate N (kg/ha) & $(\mathrm{N})$ & & & \\
\hline Low (30) & (n1) & $8126 a$ & $7999 a$ & $1,07 \mathrm{a}$ \\
\hline High (60) & (n2) & $7892 a$ & $6922 \mathrm{~b}$ & $1,16 a$ \\
\hline
\end{tabular}

Means followed by a common letter at the same column are not significantly different by DMRT at $5 \%$ level Rainfall : $11,0 \mathrm{~mm}$

The water productivity with respect to irrigation water input was ranged from $0.95 \mathrm{~kg} / \mathrm{m}^{3}$ to $1.05 \mathrm{~kg} / \mathrm{m}^{3}$ under alternate wetting and drying during the DS 2008 and from $0.96 \mathrm{~kg} / \mathrm{m}^{3}$ to 1.09 $\mathrm{kg} / \mathrm{m}^{3}$ during the WS $2008 / 2009$. The lower of water productivity might be caused by shallow water tables and rainfall supply during the wet season. 
Table 10 Average of grain yield, total water consumption and water productivity under continuously flooded at $3 \mathbf{c m}$ depth. Sukamandi. DS 2008

\begin{tabular}{|c|c|c|c|c|}
\hline \multirow{3}{*}{ Treatment } & \multicolumn{2}{|c|}{ Yield (mc : 14\%) } & \multirow{2}{*}{$\begin{array}{l}\text { Total water } \\
\text { consumption }\end{array}$} & \multirow[t]{2}{*}{ Water productivity } \\
\hline & & & & \\
\hline & & /ha) & (m3) & $(\mathrm{kg} / \mathrm{m} 3)$ \\
\hline Variety & (V) & & & \\
\hline Hybrid & (v1) & $8489 a$ & $8409 a$ & $1,05 \mathrm{a}$ \\
\hline NPT line & (v2) & $8501 \mathrm{a}$ & $9109 \mathrm{a}$ & $0,98 \mathrm{a}$ \\
\hline Ciherang & (v3) & $7892 \mathrm{~b}$ & $8702 \mathrm{a}$ & $0,95 a$ \\
\hline Plant spacing & $(\mathrm{P})$ & & & \\
\hline$\overline{(20 \times 20) \mathrm{cm}}$ & (p1) & $8327 \mathrm{a}$ & $8786 a$ & $0,99 a$ \\
\hline$\overline{(25 \times 25) \mathrm{cm}}$ & $(\mathrm{p} 2)$ & $8261 \mathrm{a}$ & $8694 \mathrm{a}$ & $1,00 \mathrm{a}$ \\
\hline $\mathrm{N}$ rate $(\mathrm{kg} / \mathrm{ha})$ & $(\mathrm{N})$ & & & \\
\hline$\overline{(30)}$ & (n1) & $8197 \mathrm{a}$ & $8929 a$ & $0,98 \mathrm{a}$ \\
\hline (60) & (n2) & $8391 \mathrm{a}$ & $8551 \mathrm{a}$ & $1,01 \mathrm{a}$ \\
\hline
\end{tabular}

Means followed by a common letter at the same column are not significantly different by DMRT at $5 \%$ level

In alternate wetting and drying (AWD), irrigation water is applied to obtain flooded conditions after a certain number of days have passed after the disappearance of ponded water. The number of days of non flooded soil in AWD before irrigation is applied can very from 1 day to more than 10 days. Bouman and Tuong (2001) in Bouman, Lampayan and Tuong (2007), 92\% of the AWD treatments resulted in yield reduction varying from just more than $0 \%$ to $70 \%$ compared to those of the flooded checks. 
Table 11 Average of grain yield, total water consumption and water productivity under alternate wetting and drying. Sukamandi. WS 2008/2009

\begin{tabular}{|c|c|c|c|c|}
\hline \multirow{2}{*}{\multicolumn{2}{|c|}{ Treatment }} & Yield ( mc : 14\%) & $\begin{array}{l}\text { Total water } \\
\text { consumption }\end{array}$ & Water productivity \\
\hline & & (kg/ha) & (m3) & $(\mathrm{kg} / \mathrm{m} 3)$ \\
\hline Variety & $(\mathrm{V})$ & & & \\
\hline Hybrid & $(\mathrm{v} 1)$ & $6101 \mathrm{a}$ & $6358 \mathrm{a}$ & $0.96 \mathrm{a}$ \\
\hline NPT line & (v2) & $5856 \mathrm{~b}$ & $5953 \mathrm{a}$ & $0.98 \mathrm{a}$ \\
\hline Ciherang & (v3) & $5880 \mathrm{~b}$ & $6140 a$ & $0.96 \mathrm{a}$ \\
\hline Plant population & $(\mathrm{P})$ & & & \\
\hline$\overline{(20 \times 20) c m}$ & (p1) & $6285 \mathrm{~b}$ & $6011 a$ & $1.05 \mathrm{a}$ \\
\hline$(25 \times 25) \mathrm{cm}$ & (p2) & $6573 a$ & $6144 a$ & $1.07 \mathrm{a}$ \\
\hline $\mathrm{N}$ rate $(\mathrm{kg} / \mathrm{ha})$ & $(\mathrm{N})$ & & & \\
\hline Low (40) & (n1) & $6283 a$ & $5876 a$ & $1.07 \mathrm{a}$ \\
\hline High (70) & (n2) & $6475 a$ & $5932 \mathrm{a}$ & $1.09 \mathrm{a}$ \\
\hline
\end{tabular}

Means followed by a common letter at the same column are not significantly different by DMRT at $5 \%$ level Rainfall : $210 \mathrm{~mm}$.

The large variability in results of AWD in the analyzed data set was caused by differences in the number of days between irrigation and in soils and hydrological conditions. Experimenting with AWD in lowland rice areas with heavy soils and shallow groundwater in China and the Philippines, Lampayan et al (2005) in Bouman, Lampayan and Tuong (2007) reported that total (irrigation + rainfall) water inputs decreased by around 15\%-30\% without a significant impact on yield. In all these cases, ground water depths were very shallow (between 10 and $40 \mathrm{~cm}$ ) and ponded water depths almost never dropped below the root zone during the drying period, thus turning AWD effectively into kind of near saturated soil culture. Research in more loamy sand and sandy soil with deeper groundwater tables in India showed reduction in water inputs of more than $50 \%$ coupled with yield loss of more than $20 \%$ compared with the flooded check. 
Didiek Setiobudi dan Hasil Sembiring

Table 12 Average of grain yield, total water consumption and water productivity under continuously flooded at 3 cm depth. Sukamandi. WS 20082009

\begin{tabular}{|c|c|c|c|c|}
\hline \multirow{2}{*}{\multicolumn{2}{|c|}{ Treatment }} & Yield (mc : 14\%) & $\begin{array}{l}\text { Total water } \\
\text { consumption }\end{array}$ & Water productivity \\
\hline & & (kg/ha) & (m3) & $(\mathrm{kg} / \mathrm{m} 3)$ \\
\hline Variety & $(\mathrm{V})$ & & & \\
\hline Hybrid & (v1) & $6550 \mathrm{a}$ & $6867 \mathrm{a}$ & $0.95 \mathrm{a}$ \\
\hline NPT line & (v2) & $6165 \mathrm{~b}$ & $6706 \mathrm{a}$ & $0.92 \mathrm{a}$ \\
\hline Ciherang & (v3) & $6233 \mathrm{~b}$ & $6480 \mathrm{a}$ & $0.96 \mathrm{a}$ \\
\hline Plant spacing & $(\mathrm{P})$ & & & \\
\hline$\overline{(20 \times 20) c m}$ & (p1) & $6087 \mathrm{~b}$ & $6878 \mathrm{a}$ & $0.88 \mathrm{a}$ \\
\hline$\overline{(25 \times 25) \mathrm{cm}}$ & (p2) & $6346 a$ & $6924 \mathrm{a}$ & $0.91 \mathrm{a}$ \\
\hline $\mathrm{N}$ rate $(\mathrm{kg} / \mathrm{ha})$ & $(\mathrm{N})$ & & & \\
\hline Low (40) & (n1) & $6532 \mathrm{a}$ & $6841 \mathrm{a}$ & $0.95 a$ \\
\hline High (70) & (n2) & $6721 \mathrm{a}$ & $6961 \mathrm{a}$ & $0.97 \mathrm{a}$ \\
\hline
\end{tabular}

Means followed by a common letter at the same column are not significantly different by DMRT at $5 \%$ level

The AWD was mostly reduces seepage and percolation flow and has only a small effect on evaporation flow. Evaporation loss decreased by $2-33 \%$ compared with fully flooded conditions. The potential benefit of AWD have been suggested : improved rooting system, reduced lodging (because of a better root system), periodic soil aeration and better control of some diseases such as golden snail. Savings in irrigation water in the alternately submerged and non submerged treatments were 53-87 mm (13-16\%) compared with the continuously submergence regime. Rice grain yields ranged from 7.2 to $8.7 \mathrm{t} / \mathrm{ha}$ and were not significantly affected by the water regimes. Water productivity was $0.91-1.48 \mathrm{~kg}$ grain $/ \mathrm{m}^{3}$ water applied. Water productivity was significantly higher in the alternately submerged and non submerged regime than in the continuously submergence regime (Belder, et al., 2002).

Ponnamperuma (1984) in Belder (2002) argues that a percolation rate of at least $1.5 \mathrm{~mm} / \mathrm{day}$ is necessary to meet oxygen demands of roots in flooded soil. Wang et al (2001) in Belder (2002) reported that plant physiological process such as photosynthesis and nutrient uptake remain unaffected when soil moisture potential is above $-25 \mathrm{kPa}$. The soil moisture potential in the Philippines did not exceed this threshold until 2 days before harvest. Water consumption in ASNS was higher than in CS because, soil cracks developed and became the major route of water percolation. The percentage of days with non submerged conditions was $38-59 \%$. 
Water input in rice-based system can be reduced through alternate wetting and drying (AWD), an irrigation regime that allows non flooded conditions for several days between flooded conditions during the growing season. The longer the non flooded period, the lower evaporation, percolation and seepage losses although soil cracks formed. The relationship between rice yield and water input in several AWD experiments in India and China. In the AWD, up to $50 \%$ less irrigation water could be applied than in conventional inundated rice system without affecting yield level. Recent experiments on AWD irrigation no yield decline beyond a reduction in water input of $20 \%$ and yield reduction of $25 \%$ at a reduction in water input of $60 \%$ (Bindraban, et al., 2006).

\section{A practical indicator to irrigate}

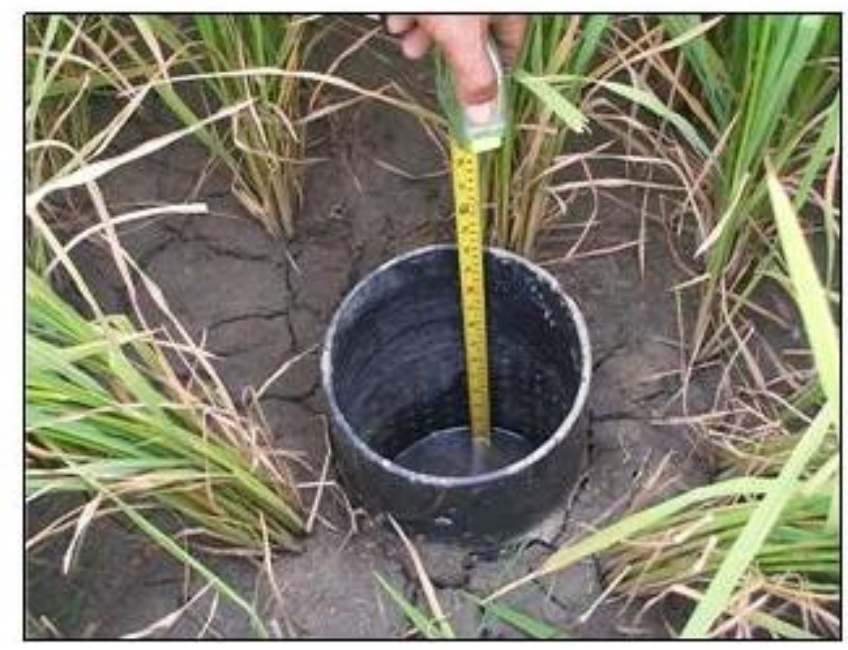

Figure 3 Field water tube to determine time to irrigate in the AWD irrigation method

\section{CONCLUSION}

The pattern of the actual water requirement $(E T+P \& S)$ showed the maximum value of 8.8 $\mathrm{mm} /$ day $(1.02 \mathrm{lt} / \mathrm{sec} / \mathrm{ha})$ for high yielding varieties (HYV) that occurred from heading to $50 \%$ flowering. Under limited water supply, irrigation water should be applied that period to prevent yield loss. Soil moisture stress at moderate level (- 0.5 bar) from heading to full flowering was significantly decreased yield about $30 \%$ when compared with the yield of continuously flooded 3 $\mathrm{cm}$ depth. This period was a critical period of HYV to soil moisture stress

For rotational irrigation purposes, information of the optimum days interval irrigation was important. It was found that 3 days irrigation interval was a critical limit for HYV to achieve higher yield. The SRI model of rice cultivation had the lowest rice yield in the lowland soil, poor drainage, clay soil texture and low permeability. The modified irrigation of the SRI plus fertilizer $\mathrm{N}$ based on LCC readings gave a greater yield as well as water productivity. 
The hybrid and NPT line rice varieties had higher yield components and grain yield than Ciherang variety. Ciherang variety was not favor to grown for the wet season, it was more productive when grown in dry season even with AWD irrigation model. The plant spacing of 25 $\mathrm{cm} \times 25 \mathrm{~cm}$ gave higher number of panicle/hill and number of spikelet/panicle under both AWD and continuously flooded $3 \mathrm{~cm}$ depth for dry and wet season consistently. The fertilizer $\mathrm{N}$ management based on SSNM with low and high rates for the early vegetative stage were not significantly affected all yield components and grain yield. The AWD irrigation could save irrigation water about $18 \%$ when compared to the continuously flooded conditions. The grain yield of the hybrid, inbred and NPT line rice varieties was higher for the dry season than wet season under both AWD irrigation and continuous flooding consistently

\section{REFERENCES}

Belder, P., B.A.M Bouman, J.H.J Spiertz, Lu Guoan and E.J.P Quilang. 2002. Water use of alternately submerged and non submerged irrigated lowland rice. In : Bouman, B.A.M., et al (Eds). Water wise rice production. IRRI-Plant Research International. $p$ : 51-61.

Bindraban, P.S., H. Hengsdijk, W.Cao, Q. Shi, T.M Thiyagarajan, W. Van Der Krogt and I.P Wardana. 2006. Transforming inundated rice cultivation. Water resources development. Vol. 22. No.1. Wageningen. The Netherlands. $p:$ 87-100.

Bouman, B.A.M., R.M Lampayan and T.P Tuong. 2007. Water management in irrigated rice. Coping with water scarcity. International Rice Research Institute. Los Banos. Philippines. 54 pages.

IRRI. 1989. Annual report for 1988. International Rice Research Institute. Los Banos. Philippines. p: 8-385.

Lu, G., R. Cabangon, T.P Tuong, P. Belder, B.A.M Bouman and E. Castillo. 2002. The effects of irrigation management on yield and water productivity of inbred, hybrid and aerobic rice varieties. In : Bouman, B.A.M., et al (Eds). Water wise rice production. IRRI-Plant Research International. P: 15-28.

McHough, O.V., T.S Steenhuis, J. Barison, E.C.M Fernandes and N.T Uphoff. 2002. Farmer implementation of alternate wet and dry and non flooded irrigation practices in the System of Rice Intensification (SRI). In : Bouman, B.A.M., et al (Eds). Water wise rice production. IRRI-Plant Research International. P: 89-102.

Murray-Rust, H. 1990. Irrigation management strategies for the dry season in rice based cropping systems. Workshop on irrigation management improvement for rice based farming system. DAE/GMU-IIMI collaborative workshop program. Departement of Agricultural Engineering. Faculty of Agricultural Technology. Gadjah Mada University. Yogyakarta. June 13-14 1990. 12 pages. 
Shi, Q., X. Zeng, M. Li, X. Tan and F. Xu. 2002. Effects of different water management practices on rice growth. ). In : Bouman, B.A.M., et al (Eds). Water wise rice production. IRRIPlant Research International. P: 3-13.

UNDP Indonesia. 2007. The other half of climate change. Why Indonesia must adapt to protect its poorest people. Jakarta. 20 pages. 